\title{
MICROBIAL PATTERN AND ANTIBIOTIC SENSITIVITY TEST OF HOSPITALIZED CHILDREN
}

\author{
John Wiwin, IGAA Putri Sri Rejeki \\ Department of Clinical Pathology, Faculty of Medicine, \\ Universitas Airlangga, Dr. Soetomo Hospital, Surabaya
}

\begin{abstract}
ABSTRAK
Infeksi sering terjadi pada anak-anak dengan hematologi maligna dan menyebabkan morbiditas dan mortalitas. Antibiotik yang diberikan harus berdasarkan hasil kultur dan tes sensitivitas antibiotik. Penelitian ini bertujuan untuk mendapatkan pola mikroba dan uji kepekaan pada anak-anak yang dirawat di bagian Hemato-Onkologi, RSUD Dr. Soetomo dari September 2012 - Februari 2013. Penelitian ini merupakan penelitian deskriptif. Data diperoleh dari catatan medis pasien di Rumah Sakit Dr. Soetomo. Dilakukan pemeriksaan 341 kultur (darah, urine, swab rektum, feses, dan lain-lain) dari 88 pasien (44 laki-laki dan 44 perempuan). Sebagian besar usia pasien adalah $<5$ tahun (58\%) dan menderita ALL (50\%). Terdapat pertumbuhan mikroba (83 kultur) dan yeast (15 kultur) dari 98 kultur. Escherichia coli, Burkholderia cefacea, dan Klebsiella oxytoca (Gram negatif) dan CONS, Staphyloccocus aureus, serta Staphylococcus sapropyticus (gram positif) ditemukan dalam kultur darah. S. aureus (gram positif) dan E. coli, Klebsiella pneumoniae, serta B. cefacea (gram negatif) ditemukan pada kultur urin. Hanya E. coli ditemukan dalam kultur swab dubur. CONS gram positif cocci kebanyakan ditemukan dalam kultur darah anak yang dirawat di bagian Hemato-Onkologi, RSUD Dr. Soetomo. E. coli adalah gram batang negatif yang kebanyakan ditemukan. Cocci gram positif menunjukkan resistensi tinggi terhadap penisilin dan kotrimoksazol. E. coli, yang sebagian besar ditemukan pada swab rektal dan urin, memiliki sensitivitas tinggi terhadap amikasin dan meropenem, tapi sangat resisten terhadap ampisilin dan ampisilin sulbaktam.(FMI 2015;51:190-192)
\end{abstract}

Kata kunci: pola mikrobial, uji sensitivitas antibiotik, pasien hemato-onkologi

\begin{abstract}
Infection often occurs in children with malignant hematology and causes morbidity and mortality in the children. Antibiotics given must be based on culture results and antibiotic sensitivity testing. This study was aimed to obtain the microbial pattern and sensitivity test in children hospitalized in the Hemato-Oncology Ward, dr. Soetomo Hospital from September 2012 - February 2013. This was a descriptive study. Data were obtained from the patients' medical records in Dr. Soetomo Hospital. There were 341 culture examinations (blood, urine, rectum swab, faecal, and others) from 88 patients (44 males and 44 females). Most of patients' age was $<5$ years (58\%) and suffered from ALL (50\%).There were microbial (83 of culture) and yeast (15 of culture) growth out of 98 cultures. Escherichia coli, Burkholderia cefacea, and Klebsiella oxytoca (Gram negative) dan CONS, Stapyloccocus aureus, and Stapylococcus sapropyticus (gram positive) were found in blood culture. S. aureus (gram positive) and E. coli, Klebsiella pneumoniae, and B. cefacea (gram negative) were found in urine culture. Only E. coli was found in rectal swab culture. CONS of gram positive cocci were mostly found in blood culture of children hospitalized in Hemato-Oncology Ward, Dr. Soetomo Hospital. E. coli was the mostly found gram negative rods. Gram positive cocci showed a high resistant to penicillin and co-trimoxazole. E. coli, mostly found in rectal swab and urine, has a high sensitivity to amikacin and meropenem, but highly resistant to ampicillin and ampicillin sulbactam.(FMI 2015;51:190-192)
\end{abstract}

Keywords: microbial pattern, antibiotic sensitivity test, hemato-oncology patient

Correspondence: John Wiwin, Department of Clinical Pathology, Faculty of Medicine, Universitas Airlangga, Dr. Soetomo Hospital, Jalan Prof. Dr. Moestopo 47, Surabaya 60131, Indonesia. email: johnwilson_mmr@yahoo.co.id

\section{INTRODUCTION}

Patients with hematologic and other malignancies often undergo treatment in hospital. Malignancy patients have a substantial risk to develop into infections and even sepsis. The source of infection can be derived from the transmission of microorganisms from other patients or from the patient's body (Hermawati 2011, Rena et al 2010). Infection is a source of morbidity and mortality in patients with malignancy. One of the causes of infections in patients with hematologic malignancies was neutropenia. Neutropenia can be caused by bone marrow suppression due to malignant disease or chemotherapy. Malignancy in patients with impaired immunity can occur so that children with malignancies susceptible to infection (Hermawati 2011, Rena et al 2010, Donowitz et al 2001, Danai et al 2006).

Rational antibiotic use is indispensable in dealing with malignancy patients who have an infection. Antibiotic 
treatment based only on empirical findings without taking into account the microbial pattern and antibiotic sensitivity test data may lead to bacterial resistance to antibiotics (Del Favero et al 2004). Therefore, the aim of the study was to find data on the patterns of bacteria and antibiotic sensitivity testing, a way to deal with an infection in malignancy, thus reduce mortality/ morbidity in accordance to the existing patterns of bacteria in hospitals.

\section{MATERIALS AND METHODS}

This study was a descriptive study using medical records of pediatric patients who are hospitalized in the Pediatric Hematology Oncology Dr. Soetomo Hospital. Samples were pediatric patients with malignancies who were treated in ward from September till February 2013. Data of age, gender, diagnosis, culture and the culture results and antibiotic sensitivity test results were taken from medical record. The data is presented in tabular form.

\section{RESULTS}

Table 1. Distribution of patients according to patient gender

\begin{tabular}{lcc}
\hline \multicolumn{1}{c}{ Gender } & Number & $\%$ \\
\hline Male & 44 & $50 \%$ \\
Female & 44 & $50 \%$ \\
\hline Total & 88 & $100 \%$ \\
\hline
\end{tabular}

Table 2. Distribution of patients according to patient age

\begin{tabular}{lcc}
\hline \multicolumn{1}{r}{ Age } & Number & $\%$ \\
\hline $0-<5$ th & 51 & $58 \%$ \\
$5-<10$ th & 24 & $27 \%$ \\
$10-15$ th & 13 & $15 \%$ \\
\hline Total & 88 & $100 \%$ \\
\hline
\end{tabular}

Table 3. Distribution of patients according to the type of malignancy

\begin{tabular}{lcc}
\hline \multicolumn{1}{c}{ Type of Disease } & Number & $\%$ \\
\hline ALL & 44 & $50 \%$ \\
Retinoblastoma & 8 & $9 \%$ \\
Limfoma & 5 & $5.6 \%$ \\
Rabdomiosarkoma & 3 & $3.4 \%$ \\
Wilms tumor & 3 & $3.4 \%$ \\
Hepatoblastoma & 2 & $2.3 \%$ \\
Neuroblastoma & 2 & $2.3 \%$ \\
Nefroblastoma & 2 & $2.3 \%$ \\
Others & 19 & $21.6 \%$ \\
\hline Total & 88 & $100 \%$ \\
\hline
\end{tabular}

Culture examination done as much as 341 specimens culture. Most of the cultures were without growth. Full details can be seen in the following table:

The number of positive growth in blood there were 18 $(25.3 \%)$, in urine were $28(40.5 \%)$, in rectal swab were $20(47.6 \%)$, in pus were $7(87.5 \%)$, in feces were 6 $(50 \%)$, and in other swabs were $4(66.6 \%)$.

Table 4. Microbial pattern of blood culture

\begin{tabular}{lcc}
\hline \multicolumn{1}{c}{ Types of Germ } & Number & $\%$ \\
\hline Gram Positive: & & \\
Staphylococcus aureus & 4 & $22.2 \%$ \\
Staphylococcus hemoliticus & 1 & $5.6 \%$ \\
Staphylococcus sapropyticus & 2 & $11.1 \%$ \\
CONS & 5 & $27.7 \%$ \\
Gram Negative: & & \\
Escherichia coli & 2 & $11.1 \%$ \\
Burkholderia cefacia & 2 & $11.1 \%$ \\
Klebsiella oxytica & 1 & $5.6 \%$ \\
Aeromonas veronii & 1 & $5.6 \%$ \\
\hline Total & 18 & $100 \%$ \\
\hline
\end{tabular}

Table 5. Microbial pattern of urine culture

\begin{tabular}{lcc}
\hline \multicolumn{1}{c}{ Types of germ } & Number & $\%$ \\
\hline Gram Positive: & 1 & $3.75 \%$ \\
Staphylococcus aureus & & \\
Gram Negative: & 7 & $25 \%$ \\
Klebsiella pneumonia & 2 & $7.14 \%$ \\
Burkholderia cefacia & 9 & $32.1 \%$ \\
Escherichia coli & 2 & $3.57 \%$ \\
Proteus mirabilis & 2 & $7.14 \%$ \\
Acinetobacter & 3 & $10.7 \%$ \\
Pseudomonas aeruginosa & 2 & $3.57 \%$ \\
Enterobacter cloaceae & 28 & $100 \%$ \\
\hline Total & & \\
\hline
\end{tabular}

From rectal swab culture bacteria of patients hospitalized, we obtained that there was only $100 \%$ of Eschericia coli (gram negative).

Table 6. Microbial patterns in feces culture

\begin{tabular}{lcc}
\hline \multicolumn{1}{c}{ Types of germ } & Number & $\%$ \\
\hline Gram Positive: & & \\
- & 0 & $0 \%$ \\
Gram Negative: & & \\
Eschericia coli & 5 & $83.3 \%$ \\
Klebsiella oxytoca & 1 & $16.7 \%$ \\
\hline Total & 6 & $100 \%$ \\
\hline
\end{tabular}


Table 7. Microbial patterns in pus culture

\begin{tabular}{lcc}
\hline \multicolumn{1}{c}{ Types of germ } & Number & $\%$ \\
\hline Gram Positive: & & \\
Staphylococcus aureus & 3 & $42.8 \%$ \\
Gram Negative: & & \\
Eschericia coli & 1 & $14.2 \%$ \\
Pseudomonas aeruginosa & 2 & $28.6 \%$ \\
Acinetobacter gaumanni & 1 & $14.2 \%$ \\
\hline Total & 7 & $100 \%$ \\
\hline
\end{tabular}

\section{DISCUSSION}

The results of antibiotic susceptibility testing against gram-negative bacteria $E$. coli in blood cultures by first antibiotic line tobramycin has 50\% sensitivity and 50\% resistance. The use of second-line antibiotics are amikacin had a sensitivity of $100 \%$, amoxicillin clavulanat $(50 \%)$, and co-trimoxazole $(100 \%)$. Antibiotic susceptibility test results on B cefacea 50\% sensitivity obtained with the first-line drug cotrimoxazole and $100 \%$ with ceftazidime and second-line drugs meropenem.

The results of antibiotic susceptibility testing against gram-positive blood culture with CONS on first-line antibiotics penicillin has $25 \%$ sensitivity and $100 \%$ resistant to cotrimoxazole. The results of antibiotic susceptibility testing in Staphylococcus aureus 50\% sensitivity obtained with the first-line drug cotrimoxazole.

The results of antibiotic susceptibility testing against gram positive bacteria Staphylococcus aureus in the urine culture was $100 \%$ sensitive to first-line drugs erythromycin and co-trimoxazole. The results of antibiotic susceptibility testing against gram-negative bacteria $E$. coli which turned out to be resistant to firstline drugs ampicillin $100 \%, 71 \%$ sensitive to gentamicin, tobramycin and $85 \%$ sensitive. Second-line drug sensitivity was $100 \%$ amikacin, ampicillin sulbactam $62 \%, 28 \%$ and cefuroksim. The results of antibiotic susceptibility testing against gram-negative bacteria Klebsiella pneumoniae are resistant to first-line drugs gentamicin and $71 \%$ in the second-line drugs: amikacin resistant to ampicillin sulbactam $28 \%$ and $85 \%$, and $71 \%$ clavulanat amoxicillin.

The results of antibiotic susceptibility testing against gram-negative bacteria $E$. coli in rectal swab culture first-line antibiotic gentamicin resistant ampicillin 35\% and $92 \%$. The use of second-line antibiotics are amikacin had a sensitivity of $100 \%$ and were resistant to ampicillin and ceftriaxone sulbactam $65 \%$ to $45 \%$.

\section{CONCLUSION}

CONS were Gram (positive) cocci mostly found in blood culture of children hospitalized in the HematoOncology Ward, Dr Soetomo Hospital. E. coli were Gram (negative) rods mostly found. Gram (positive) cocci showed a high resistance to penicillin and erythromycin but still sensitive to linezolid. E. coli was mostly found in rectal swab and urine having a high sensitivity to amikacin and meropenem but highly resistant to ampicilin and ampicilinsulbactam.

\section{REFERENCES}

Danai PA, Moss M, Mannino DM, Martin GS (2006). The epidemiology of sepsis in patients with malignancy. Chest 129, 1432-1440

Del Favero A, Bucaneve G, Furno P (2004). Choice of empirical therapy and prophylaxis. Hematol J 5 Suppl 3, S53-58

Donowitz GR, Maki DG, Crnich CJ, Pappas PG, Rolston KV (2001). Infections in the neutropenic patient--new views of an old problem. Hematology Am Soc Hematol Educ Program, 113-139

Hermawati R, Rejeki IGGA PR (2011). Pola kuman dan kepekaan antibiotika kultur blood pada penderita anak di IRNA Anak RSUD Dr Soetomo Surabaya.

Rena RA, Suega K, Bakta IM (2010). Pola kepekaan bakteri pada pasien keganasan hematologi di RSUP Sanglah Denpasar. Journal of Internal Medicine 11, 104-109 